\title{
Recent African Literature
}

\section{Author(s): E. Heawood}

Source: The Geographical Journal, Vol. 10, No. 2 (Aug., 1897), pp. 172-179

Published by: geographicalj

Stable URL: http://www.jstor.org/stable/1774599

Accessed: 26-06-2016 10:53 UTC

\section{Your use of the JSTOR archive indicates your acceptance of the Terms \& Conditions of Use, available at}

http://about.jstor.org/terms

JSTOR is a not-for-profit service that helps scholars, researchers, and students discover, use, and build upon a wide range of content in a trusted digital archive. We use information technology and tools to increase productivity and facilitate new forms of scholarship. For more information about JSTOR, please contact support@jstor.org.

The Royal Geographical Society (with the Institute of British Geographers), Wiley are collaborating with JSTOR to digitize, preserve and extend access to The Geographical Journal 
Temperatures.

\begin{tabular}{|c|c|c|c|c|c|c|c|}
\hline \multirow{2}{*}{\multicolumn{3}{|c|}{ Place. }} & \multirow{2}{*}{$\begin{array}{l}\text { Height above } \\
\text { sea-level. }\end{array}$} & \multirow{2}{*}{ Montb. } & \multicolumn{2}{|c|}{ Shade. } & \multirow{2}{*}{ Remarks. } \\
\hline & & & & & Maximum. & Minimum & \\
\hline Chinde ... & .. & & Feet. & & 72 & 61 & In hotel room \\
\hline On Shire river & boat & $\ldots$ & - & July & 81 & 59 & In cabin of boa \\
\hline Mandala & $\ldots$ & $\ldots$ & 3300 & ", & 87 & 66 & In house \\
\hline Matope ... & $\cdots:$ & $\ldots$ & - & $"$ & 75 & 65 & \\
\hline On upper Shire & e river & $\ldots$ & $\overline{-}$ & ", & 77 & 58 & In cabin of boa \\
\hline Fort Johnston & $\cdots$ & $\ldots$ & 1450 & & 91 & 58 & In tent \\
\hline Bandawe & $\ldots$ & $\ldots$ & 1600 & August & 92 & 52 & " \\
\hline Hora & $\cdots$ & $\ldots$ & 4710 & 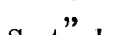 & 80 & 54 & $"$ \\
\hline Käsungu & $\cdots$ & $\cdots$ & 3325 & September & 88 & 51 & " \\
\hline Masulg, & $\begin{array}{l}\cdots \\
\cdots\end{array}$ & $\begin{array}{l}\cdots \\
\ldots\end{array}$ & 3520 & October & 95 & $\begin{array}{l}52 \\
65\end{array}$ & $"$ \\
\hline Chenunda's & $\cdots$ & $\ldots$ & 2972 & & 104 & 65 & $"$ \\
\hline Chuaula's & $\cdots$ & $\cdots$ & 1900 & November & 109 & 67 & " \\
\hline Mafuta's & $\cdots$ & $\cdots$ & 3300 & December & 89 & 64 & \\
\hline Kotakota & $\cdots$ & $\cdots$ & 1580 & January & 93 & 70 & In fort \\
\hline Mandala... & $\ldots$ & $\ldots$ & 3418 & 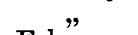 & 79 & 70 & In house \\
\hline$\cdots$ & $\cdots$ & $\cdots$ & - & February & 76 & 68 & $"$ \\
\hline
\end{tabular}

\section{RECENT AFRICAN LITERATURE.}

By E. HEAWOOD, M.A.

That the age of great exploring journeys in Africa is well-nigh over, and its place taken by one of steady political development, is shown by a glance at the principal African books of the past few months, a large proportion of which deal with the extension or maintenance of European influence in one quarter or another of the continent.

Our list is, however, headed by the record of a journey * which, from the extent of little-known country traversed, seems to belong rather to the past than the present order of things. Dr. Donaldson Smith has much to tell of dangers and difficulties successfully overcome, whether arising from the determined opposition of Abyssinian soldiery, the fierce attacks of Galla tribes, or the necessity of journeying through trackless forests or waterless deserts. The book is written in a lively and piquant style, and-possibly from the author's readiness to look at the bright side of things, and his appreciation of the untrammelled life in the African wilds-we carry away from its perusal a far pleasanter picture of Central Africa than is supplied by many books of travel. He speaks in high terms of the beauty and healthiness of much of the country, and lays stress on its commercial and agricultural value. Sportsmen will find much to their taste in Dr. Smith's numerous rencontres with the large game of North-East Africa, with which his rifle played constant haroc.

* 'Through Unknown African Countries.' By A. Donaldson Smith, M.D., F.R.G.s. Illustrated. London: Arnold. 1897. 
Unlike some recent writers, he puts much faith in the express rifle (the .577), which he preferred to the eight-bore even against elephants and rhinoceros. The geographical results of the journey have already been so fully dealt with in our pages that it is needless to refer to them here. It may, however, be remarked that the difficulty Dr. Smith finds in supposing the Omo to make itself a way westward across the barrier of mountains seen to the north of Lake Abbaya does not exist if, as seems probable and is indicated in a recent map published in Petermanns Mitteilungen, the whole course of the river lies to the westward of the range.

Dr. Smith came in contact with many interesting tribes, from the powerful Boran Gallas to the Dume pygmies and the Adone negroes of the Jub. He shows a genuine liking for his Somali followers, and a quick apprehension of the various traits of character exhibited by the races met with. In a supplementary chapter he gives his views with regard to the present political situation in the countries he passed through, differing materially in his conclusions from other recent writers. He urges the necessity of curbing the arrogant pretensions of King Menelek to sovereignty in the countries south of Abyssinia, and holds that all civilized nations should concur in putting down the "brutal rule" of that sovereign. He considers that the Abyssinians would be unable to resist a well-organized force brought against them. The book is well illustrated, and contains, in appendices, reports by various scientists on the zoological and other collections made by the author. The maps are those already published in this Journal.

In Mr. Selous's latest book, * we have a narrative of the earlier stages of the Matabele insurrection by one who not only took a large part himself in the events recorded, but possessed ample opportunity of learning at first hand the details of occurrences at which he was not actually present. But the book is not a mere record of facts. It is useful as presenting the ideas of a shrewd observer on many questions affecting the future of South Africa, and although the author shows a keen sense of the injustice of the accusations which have been levelled against the white settlers, he is evidently actuated by an honest desire to show matters in their true light, and to point the way to a solution of existing problems in accordance with the best interests of the country and its inhabitants, both European and native. As regards the causes of the insurrection, Mr. Selous holds that, while the irksomeness of the labour regulations to a race indolent by nature, and the hardships arising from the rinderpest were important factors in the case, the Matabele were really surprised into revolt, in many cases against their better judgment, by a few leading spirits, who since the former war

* 'Sunshine and Storm in Rhodesia.' By Frederick Courteney Selous. London Rowland Ward. 1896. 
had been awaiting an opportunity for revenge. He does not hesitate to avow his opinion that the removal of the white police was the event which made the rising possible, and thinks that with suitable precautions there should be no danger of its repetition. The country, he holds, is bound by the inexorable law of the survival of the fittest to be ruled by the white man, and the black man must either conform to his laws or succumb. The Dutch element is much larger than is generally supposed, and Mr. Selous points with satisfaction to the cordial relations maintained between them and the British during the revolt. The great desideratum in South Africa generally is the encouragement of goodwill between the two races.

Another chapter in the history of the gradual conquest of Africa by the white man is supplied by Captain Hinde, * well known as one of the lieutenants of Baron Dhanis in his successful campaign against the Arabs of the upper Congo in 1892-94. Dealing as it does with a region which may be truly described as one of the dark places of the Earth, it contains of necessity an abundance of harrowing details of bloodshed, cannibalism, and cruelty; but the importance of the events recorded as marking the final struggle for supremacy between European and Arab influence in Central Africa gives a special value to the detailed account of the campaign supplied by the author. Incidentally, much useful information is given with respect to the tribes of the Central Congo basin, one of the most interesting being perhaps that of the Waginia (Wenya or Wagenya of Stanley), the general ferrymen of the upper Congo, who, though spending their life on the water, are very bad swimmers, and do not even make their own canoes. Captain Hinde gives a vivid description of the oppressive stillness of the African forest, bearing out the statements of other observers as to the scarcity of animal life and the sombre tints of the vegetable world. 'The exploring work carried out by him on the upper Lualaba has already been fully described in the Journal (vol. v. pp. 420 et seq.).

Although likewise largely a record of fighting, Major Macdonald's book $\dagger$ is less concerned than either of the two last with the more revolting aspects of savage warfare, and, taken as a whole, presents a satisfactory picture of victories won in the cause of civilization in the extensive regions of British South Africa. The many-sided nature of Major Macdonald's work in the country, from his first arrival in 1891 to take charge of the railway survey, to his departure from Uganda in 1894 after the final pacification of that kingdom, makes him peculiarly fitted to write the history of the most momentous period in the

* 'The Fall of the Congo Arabs,' By Sidney Langford Hinde. London: Methuen 1897.

† 'Soldiering and Surveying in British East Africa.' By Major J. R. L. Macdonald, R.E. Maps and Illustrations. London: Arnold. 1897. 
establishment of British influence in East Africa, and the completeness of his narrative is enhanced by the care he has taken to record the achievements of all who assisted in the work during the period in question. He gives a clear and unbiassed account of the unfortunate disturbances in Uganda previous to his arrival, based on his careful inquiries made under the direction of Sir Gerald Portal, and bears striking testimony to the great influence for good exercised by the missionaries in that country. He speaks generally in a hopeful vein with regard to the future of British East Africa, and is enthusiastic in his description of the Masai grazing-grounds, with their carpet of white clover, and fertile country waiting for inhabitants. The book contains several maps and some striking illustrations from the author's sketches and from photographs taken during the railway survey.

Under a somewhat misleading title,* Dr. Aurel Schultz describes a journey made over twelve years ago in company with Mr. A. Hammar, from Natal to the region of the Chobe and Okavanga rivers. The book forms a readable account of sport and adventure in South Africa, although the personal incident bears a somewhat large proportion to the geographical detail. It was, of course, only in the neighbourhood of the furthest point reached that any new country was traversed, but the information regarding the Chobe and Okavanga and the country between them is of value by reason of the meagre nature of the information supplied by other travellers to that region. The accounts of the vast herds of wild animals in the neighbourhood of the Chobe recall those of the pioneer travellers in South Africa early in the century. Between the Chobe and the Okavanga the country consisted mainly of dreary sand-belts, in which the travellers suffered from want of water. The latter river was struck at the town of Debabe or Indala-apparently the successor of the chief visited by Green-whose greed and treachery placed the party in some danger. Dr. Schultz speaks in glowing terms of the Okavanga and the country on its banks, and considers that the river is capable of becoming an important highway through the country. Geographically the most interesting point is the question of the bifurcation of the river. Dr. Schultz did not see the diverging-point of the supposed branch to the Chobe, but his conclusions, based on the discovery of an important stream entering the latter river from the west, were confirmed by the native accounts, while the general nature of the country renders such a bifurcation extremely probable. The book contains some good illustrations of scenery, and a map of the route by Bartholomew.

Before passing to works published abroad, mention must be made of the lately issued fourth volume of Mr. Lucas's well-known 'Historical

* 'The New Africa: A Journey up the Chobe and down the Okavanga Rivers.' By Aurel Schultz, M.D., and August Hammar, c.e. London: Heinemann. 1897. 
Geography of the British Colonies,' * which relates to South and East Africa. It is divided into two parts, the first historical, the second geographical; and the great political changes which have taken place of late years in this part of the world renders the former particularly valuable. It is enough to say that the reputation for clearness and accuracy attained by the earlier volumes is fully sustained in the present issue.

Foreign works relating to Africa have been less numerous than usual during the past twelve months. Perhaps the most permanently valuable is Dr. K. Dove's account of the scientific results of his journey of 1892-93 in German South-West Africa, which has appeared as a supplementary number of Petermanns Mitteilungen (No. 120, 1896). $\dagger$ The journey was undertaken with a view to promoting the economic development of the colony, and particular attention was paid to the study of its climatic conditions as affecting the prospect of settlement by white men. The section devoted to climate is therefore by far the fullest, although many other points connected with the physical and economic geography of the country are also touched upon. Dr. Dove had to choose between securing a complete series of meteorological observations from a restricted area, or less detailed results from a larger extent of country, and, considering the objects in view, he wisely chose the latter, so that we now possess a good general idea of the climate of Southern Damaraland, in every way the most important part of the German territory. The observations also possess a special value from the care which Dr. Dove took to shelter the thermometers from the effects of the solar radiation, the want of which has often vitiated the results obtained by other observers. As in his previous writings, Dr. Dove lays stress on the healthiness of the country, and its suitability for cattle-rearing by settlers possessed of a certain amount of capital. The prospects of success in the working of minerals he regards as extremely doubtful.

Although relating to two of his earlier journeys in the Northern Sahara, M. Foureau's reprint of his official report, originally published in 1893 , is to be welcomed on account of the very limited circulation which it then attained. $f$ In addition to the traveller's journal, the report contains valuable records of meteorological and other observations, notes on the distribution of plants, etc., and is altogether a solid contribution to our knowledge of the desert regions south of Algeria. It

* Oxford : Clarendon Press. 1897.

+ A popular account of the same journey was previously published by Dr. Dove as an independent work, with map and illustrations (Berlin: Allgemeiner Verein für Deutsche Litteratur. 1896). For a summary of the scientific results, see Journal, vol. iv. p. 271.

$\ddagger$ Fernand Foureau, 'Au Sahara: Mes deux Missions de 1892 et 1893.' Paris : Challamel. 1897. 
is to be wished that equally full reports of M. Foureau's later journeys may be published. The large-scale map which is added is a reproduction of M. Foureau's original itineraries, and does not contain the corrections introduced by his later journeys, but he hopes to publish in time a map which shall embody the whole of his observations.

Commandant Toutée's voyage of exploration on the middle Niger has bəen somewhat eclipsed by Lieut. Hourst's recent successful expedition, but the results .were none the less valuable, and the account lately published* includes not only the incidents of the journey, but useful information on the peoples of the countries traversed, their manners and customs, industries, etc., as well as on the commercial possibilities of the Niger region. The author thinks highly of the use of the river as a highway to the French Sudan, pointing out that, whereas the journey from Timbuktu to Saint Louis occupies three months, his own return voyage from his farthest point up the river, three-fourths of the distance from the sea to Timbuktu, took only twenty-seven days, in spite of many hindrances. The region of the middle Niger is, he thinks, certainly worth the attention of Europeans in spite of the absence of mineral wealth and the small variety of articles of exchange yet available. It is only, however, powerful companies that will be able to make head against the initial difficulties of commercial enterprise. The map which illustrates the book is, unfortunately, on too small a scale to allow the detail to be clearly legible.

M. E. Foa publishes in separate books accounts of his big-game shooting, and of his travels, in 1891-93 in the Portuguese territory southwest of Lake Nyasa and north of the Zambesi. $†$ This was then new and unknown country, and the existing maps, based on hearsay halfcaste information of circ. 1820-1830, are widely wrong. M. Foa is an ardent and indefatigable hunter who has much to say on the habits of his game, and his first and larger work $\ddagger$ is extremely lively and interesting. The other book $\S$ contains a general account, well suited to French readers, of the various colonies between Cape Town and Lake Nyasa (all of which he touched or traversed), but its description of the new country north of the Zambezi is somewhat meagre, and the smallscale map adds nothing to our knowledge. Starting from Tete, M. Foa made his headquarters on Mount Chuïta, and then near Muchena, where a Portuguese garrison was massacred in 1888 by the chief of Makangaland. He visited Missale near the still undetermined charter-land frontier

\footnotetext{
* Commandant Toutée, 'Dahomé, Niger, Touareg. Récit de Voyage.' Paris : Colin. 1897.

$\dagger$ This notice of M. Foa's books is by Mr. J. T. Wills.

+ 'Mes grandes chasses en Afrique Centrale.' Par Ed. Foà. Paris: Fermin Didot. 1897.

§ 'Du Cap au lac Nyassa.' Par Ed. Foà. Paris : Plon. 1897.

No. II.-Algust, 1897.] 
(at about $14^{\circ} 15^{\prime}$ S., $33^{\circ}$ E.), where gold-workings were opened and abandoned by some half-caste Tete traders sixty years ago. His previous trip to Undi, whose signature to mineral concessions was at that time in much request, nearly proved fatal. Four rivers cross the uninhabited plain, afterwards joining the Zambezi by one gorge. These were crossed by M. Foa dryshod and thirsty in October, but became impassable and 100 to 200 yards wide in November, so that famine stared him in the face, and he became, besides, embroiled in a native war. Finally, amidst unheard-of difficulties, he arrived at Chuiita after a seventy hours' fast.

A brief reference to one or two less strictly geographical works relating to Africa must suffice. Captain C. de la Jonquière supplies a useful sketch * of the history of the Italian connection with Eritrea, illustrated by maps. He treats the subject in a more dispassioned manner than is usual on the part of French writers on colonial questions, and thinks that Italy may still play an important part in the future of Abyssinia, if she is content to regard the substance rather than the name in her endeavours to make her influence felt. Captain E. de Vasconcellos, secretary of the Lisbon Geographical Society, has issued a succinct account $\dagger$ of the Portuguese colonies in their geographical, political, and economical aspects, the greater part of which naturally refers to Africa. It contains valuable details on the administration and resources of the colonies, based on reliable statistics. It may be noted that the trade of Angola is shown in a more favourable light than in Dr. Esser's paper, lately published by the Berlin Geographical Society.

As the first volume of an Italian scientific series, Giuseppe Sergi has published a detailed study $\ddagger$ of the Hamitic race in Africa, regarded from a purely anthropological point of view. From an examination of the physical characters of the people of North Africa, especially the form of the skull, on the persistence of which as a race-characteristic he lays much stress, he regards the Hamites as forming, with most of the peoples of South Europe and possibly the Semites, a definite species of mankind, which he names "Eurafrican." Two main branches, the eastern and northern, are to be distinguished in Africa, the dividing-line coinciding roughly with the western limit of the Nile basin. The former includes, among other subdivisions, the Nubians and those of the Nilotic tribes which, in the mixture of races, have acquired the Hamitic characters in the most marked degree. The book is abundantly illustrated with examples of the various groups. In

* 'Les Italiens en Erythrée.' Paris: Charles-Lavauzelle.

† 'As Colonias Portuguezas.' Lisbon: Companhia Nacional Editora. 1896.

$\ddagger$ 'Biblioteca di Scienze Moderne,' No. 1. 'Africa: Antropologia della Stirpe Camitica.' 'Turin: Bocca. 1897. 
conclusion, a study by $\mathrm{J}$. Toutain of the Roman colonization in North Africa, ${ }^{*}$ issued as a publication of the Écoles Françaises d'Athènes et de Rome, deserves mention. Two chapters deal with the geographical position and distribution of the cities, the rest of the work giving a full account of their architectural and other characters, and of the life of their inhabitants.

\section{THE FIRST CROSSING OF SPITSBERGEN. $\dagger$}

The first achievements of Sir Martin Conway as arctic explorer are fitly chronicled in the sumptuous volume recently published for him by Messrs. J. M. Dent \& Co. Those members of the Society who were present at the meeting on January 25 last, when Sir Martin gave a condensed account of his adventures and exhibited some of his trophies in the shape of photographs and sketches, will be glad to read the narrative in detail, and to revel once more in the weird scenes of solitude and desolation so largely responsible for the prevailing epidemic of "arctic fever." Sir Martin Conway's work in the province he has so peculiarly made his own is sufficiently well known and appreciated to render it unnecessary for us here to describe how this particular example has been carried out; we need only wish him all speed with the volume on the history of Spitsbergen exploration promised in the introductory chapter, and proceed to chronicle briefly what he and his colleagues have done to add to that history.

The peculiarity of arctic exploration hitherto has been that it is almost wholly the work of navigators. Our knowledge of the topography of nearly all the arctic archipelagoes is limited to that usually required by the marine surveyor, who notes the outs and ins of the coast-line, takes the bearings of the chief mountain summits, and is content to sketch the geographical features generally from the immediate neighbourhood of the coast. Lord Dufferin was probably the first to point out that Spitsbergen is, as Sir Martin Conway puts it, "a land of mountains and glaciers, of splintered peaks and icy bays"-altogether beyond the sphere of the navigator, but eminently worth visiting for the scientific mountaineer. The object of this expedition was accordingly to cross Spitsbergen, and reveal the topographical and geological character of the interior.

The first landing was effected at Advent Bay, the party consisting of Sir Martin Conway, Dr. J. W. Gregory, Mr. E. S. Garwood, Mr. A. Trevor-Battye, Mr. H. E. Conway, and two Norwegian sailors. It was supposed that a series of bogs would first have to be crossed, and that these would be succeeded by an inland plateau on which sledges could

* 'Les Cités Romaines de la 'Tunisie.' Paris: Fontemoing. 1896.

+ “The First Crossing of Spitsbergen." By Sir W. Martin Conway, s.A., F.s.A. J. M. Dent \& Co. 1897 . 